\title{
ETIKA KOMUNIKASI DALAM BERDISKUSI
}

\author{
Qudratullah $^{1^{*}}$, Rosniar $^{2}$ \\ Program Studi Komunikasi dan Penyiaran Islam Institut Agama Islam Negeri Bone, Indonesia ${ }^{1,2}$ \\ Email: qudratullah@iain-bone.ac.id ${ }^{1 *}$, niamatasgimi@yahoo.co.id ${ }^{2}$
}

\section{Artikel info \\ Artikel history \\ Diterima : 14-12-2020 \\ Direvisi : 07-01-2021 \\ Disetujui : 18-01-2021}

Kata Kunci: etika; komunikasi; diskusi; da"wa; islamic communicatiom

Keywords: ethics; communication; discussion; dakwah; komunikasi islam

\begin{abstract}
Abstrak
Penelitian ini bertujuan untuk menggali etika-etika yang seharusnya diterapkan dalam diskusi agar diskusi dapat berjalan dengan baik tanpa melahirkan konflik yang terjadi antarpihak yang berdiskusi. Metode yang digunakan adalah kualitatif deksriptif, di mana data-datanya diambil melalui riset kepustakaan yang sesuai dengan pembahasan kajian. Data primer diambil dari literatur sedangkan sumber data sekunder diambil dari dokumen-dokumen pendukung. Hasil kajian ini mengungkapkan bahwa memilih perkataan yang baik sesungguhnya menjadi bagian dari upaya kita untuk menghargai orang lain dan diri kita sendiri. Artinya orang lain ketika berkomunikasi dengan kita juga akan mampu menghargai ketika kita juga menghargai mereka. Seringkali manusia tidak dihargai karena dirinya sendiri tidak mampu menghargai orang lain. Islam mengajarkan untuk berdiskusi dengan memberi manfaat, menggunakan kalimat yang baik dan sopan, bersikap lemah lembut, dengan melalui diskusi dengan penuh hati-hati dan tenang serta mengutamakan untuk menahan amarah dan berlapang dada menerima pendapat orang lain. Dalam proses diskusi sebaiknya dimuat dalam forum yang harmoni, berusaha memberikan argumentasi yang berorientasi pada kebenaran dan menciptakan suasana yang santai dan nyaman. Hal terpenting adalah bagaimana forum diskusi tersebut berjalan dengan penuh sikap saling menghargai tanpa memperlihatkan keegoisan pribadi.
\end{abstract}

\section{Abstract}

This study aims to find ethics that should be applied

in discussions so that discussions can run well without creating conflicts between the parties in discussion. The method used is descriptive qualitative, the data is taken through library research in accordance with the study discussion. Primary data were taken from literature, while secondary data sources were taken from supporting documents. The results of this study reveal that choosing what words really are part of our efforts to respect others and ourselves. This means that other people when communicating with us will also be able to appreciate when we also respect them. Often humans do not play because they themselves are not able to respect others. Islam teaches discussion with benefits, using sentences that are good and polite, bad and weak, through careful and calm discussion and prioritizes restraining anger and tolerating the opinions of others. The discussion process, which should be published in an adverse forum, seeks to provide truth-oriented arguments and create a relaxed and comfortable atmosphere. The most important thing is how the discussion forum operates in a respectful manner without personal selfishness.

Korespondence author: Qudratullah Email: qudratullah@iain-bone.ac.i artikel dengan akses terbuka dibawah lisensi 


\section{Pendahuluan}

Diskusi merupakan suatu proses komunikasi yang teratur dengan melibatkan sekolompok orang, di dalamnya terjadi pembicaraan dengan mengangkat topik tertentu dan setiap orang yang terlibat mendapatkan kesempatan yang sama untuk menyampaikan pendapat, mengeluarkan ide, dan memberikan solusi dari permasalahan yang diangkat. Dikemukakan Kamisa, diskusi menjadi sarana bertukar pendapat yang bertujuan untuk mendapatkan soludi dri masalah yang ada dan menemukan sebuah kebenaran, atau sebuah forum ilmiah yang dilakukan dalam bentuk tanya jawab untuk membahas sebuah masalah (Kamisa, 2013). Diskusi tidak hanya bisa dilakukan dalam situasi formmenggal misalnya forum akademis, organisasi, dan institusi tetapi bisa juga terjadi dalam lingkungan keluarga, hubungan antarpribadi dan lainlain. Seiring perkembangan zaman, diskusi juga semakin beragam. Diskusi bahkan dapat dilakukan menggunakan pemanfaatan teknologi informasi dan komuninikasi. Namun seiring perkembangan tersebut, tontonan diskusi menjadi hal yang disayangkan tanpa kendali dan kurang mengedepankan etika. Misalnya saling adu fisik, menjatuhkan orang lain dalam forum, menggunakan kalimat kasar dan sebagainya. Kondisi tersebut tidak hanya terjadi pada forum yang biasa saja, tetapi terkadang terjadi pada lembaga pemerintahan. Beberapa kejadian yang mengarah pada masalah tersebut dimuat dalam media, di antaranya berita dengan judul "Adu Jotos Dua Kubu Massa Warnai Rapat Dengar Pendapat
Dampak Batu
Bara
di
DPRD Gresik"

(https://surabaya.tribunnews.com/2020/01/29/adu-jotos-dua-kubu-massa-warnai-rapatdengarpendapat-dampak-batu-bara-di-dprd-gresik.), "Anggota DPR di Taiwan lempar usus dan jeroan babi dan saling tonjok, saat digelar rapat membahas pelonggaran impor daging dari AS" (https://www.bbc.com/indonesia/dunia-55100265) dan "Kesal, Ketua DPRD dan

Kepala BKD Tolitoli Nyaris Adu Jotos Rapat" (https://www.kompas.tv/article/105592/kesal-ketua-dprd-dan-kepala-bkd-tolitoli-nyaris-adujotos-saat-rapat).

Demikian halnya dalam proses pelaksanaanya, diskusi mengundang berbagai gagasan dengan tujuan agar dapat memeroleh atau mendapatkan kesepakatan bersama. Diksusi ini menjadi salah satu sarana dalam menyamakan pendapat lewat forum-forum yang dibuat.

Pemilihan topik dilakukan sesuai dengan isu yang sedang ramai diperbincangkan di masyarakat sehingga menarik minat peserta. Selain itu juga memberikan asas manfaat sehingga membuat peserta termotivasi untuk mengeluarkan idenya dalam pemecahan masalah. Oleh karena itu dibutuhkan penguasaan topik dalam berdiskusi yang harus dimiliki oleh setiap pihak yang terlibat dalam diskusi baik itu peserta maupun moderator yang mengarahkan jalannya diskusi.

Setiap orang harus kritis namun menerima bila ada pendapat yang lebih baik, ia bukanlah tempat untuk membenarkan dan menyalahkan pendapat seseorang, tapi bagaimana ide dimunculkan dan solusi diberikan. Karena itu, perlu dibangun sikap saling memahami eksistensi masing-masing, meningkatkan kerja sama dan mendekatkan perbedaan yang ada. Karena memang memang pada dasarnya pembicaraan dilakukan dengan sikap saling menghormati, saling mengerti, saling percaya, dan saling menerima orang lain.

Sebagaima diskusi merupakan suatu proses komunikasi yang teratur dengan melibatkan sekolompok orang dalam interaksi maka lisan mempunyai peran yang sangat penting dalam hal pembicaraan. Karena pada dasarnya cara berkomunikasi yang efektif di antaranya adalah dengan pemilihan kalimat yang tepat, perkataan yang lembut dan cerdas sehingga tercipta komunikasi efektif, di mana tindakan dan kata-kata seseorang mempengaruhi bagaimana orang lain memberikan tanggapannya, begitu pula sebaliknya (Pujiati \& Triadi, 2016).

Seiring dengan perkembangan teknologi informasi dan komunikasi, diskusi kini telah dapat dilakukan melalui media virtual tanpa mengenal jarak dan waktu. Tetapi tentunya tidak 
berbeda jauh dengan diskusi yang dilakukan langsung di sebuah tempat. Apalagi jika menyinggung mengenai etika dalam berdiksusi yang merupakan hal terdepan yang harus diterapkan dengan baik oleh semuah pihak tanpa memandang kelas ataupun jabatan. Ada beberapa hasil penelitian terdahulu yang memiliki relevansi dengan penelitian ini.

Di antaranya a) Etika Komunikasi dalam Persfektif Islam, yang menyebutkan bahwa Keterampilan berkomunikasi yang benar dan tepat akan membawa individu mengarah pada kesuksesan dan memberikan manfaat bagi orang lain.

Namun, jika hanya mementingkan hal-hal lain seperti bagaimana berbicara dengan itu tidaklah sempurna jika tanpa menggunakan etika dalam berbicara. Diawali era reformasi, masyarakat Indonesia telah mendapatkan kebebasannya dalam mengemukakan pendapat kepada siapa pun dan dengan cara apa pun. Namun diperlukan etika untuk mendapatkan hasil yang lebih baik (Muslimah, 2016). b) Etika Diskusi dalam Perspektif Islam, yang menguraikan bahwa Pada sebuah forum diskusim tentu terdapat adu argument dari pihak yang terkait dengn forum yang bertujuan untuk mencapai tujuan yang diinginkan. Ada diskusi yang diakhiri dengan senyuman dan ada pula yang berakhir dengan konflik perselisihan yang berkepanjangan. Oleh karena itu, sangat dibutuhkan kode etik dalam berdiskusi sehingga dapat kondusif dan konstruktif. Ada tujuh etika dalam perspektif al-Qur"ean yang dapat diterapkan dalam berdiskusi, di antaranya dimulai dengan niat yang tulus, fokud mendengarkan dan memperhatikan, memberikan argumentasi yang akurat dan benar, lugas dalam beretorika, objektif dan adil, kooperatif, bersedia mengalah dan tidak egois. Dengan begitu, penerapan etika tersebut dapat menghindarkan semua pihak dari berbagai konflik dalam berdiskusi sehingga mencapai tujuan bersama (Zulfikar, 2019).

Sebagai makhluk sosial seseorang membutuhkan perasaan dihargai, eksistensi sebagai manusia butuh dihormati, dan dihargai orang lain. Oleh karena itu dibutuhkan etika komunikasi dalam berdiskusi. Berbicara etika berarti berbicara tentang perbuatan atau perilaku manusia (sebagai objek materil) sedangkan kebaikan atau keburukan atau bermoral atau tidak bermoral dari tingkah laku tersebut adalah objek formalnya. Nilai-nilai atau norma- norma moral ini kemudian menjadi pegangan seseorang atau suatu kelompok dalam mengatur tingkah lakunya.

Etika atau moral menjadi tolok ukur untuk menentukan betul-salahnya sikap atau tindakan manusia jika dilihat dari segi baik-buruknya sebagai manusia dan bukan sebagai pelaku peran tertentu dan terbatas, misalnya seseorang yang sering berkata kotor dan memaki orang lain disebut tidak beretika atau tidak bermoral, baik itu dia sebagai pejabat atau rakyat biasa.

Dari sini bisa kita memaknai bahwa etika menjadi sebuah pertimbangan nilai (value judgement), ini adalah sebuah proses dalam komunikasi di mana komunikator (subjek komunikasi) mengemas pikirannya dengan bahasa, sebelum pesan disampaikan kepada komunikan (objek komunikasi). Bahasa yang diproduksi sebagai simbol menyampaikan pesan harus kita akui tidak bebas dari pertimbangan nilai, apakah beretika atau tidak beretika. Wujud etika dalam berkomunikasi tidak hanya berkaitan dengan tutur kata yang baik.

Tetapi juga harus berangkat dari niat tulus yang diekspresikan dengan ketenangan, kesabaran, dan empati seseorang dalam berinteraksi. Konsep ideal yang demikian akan menghasilkan komunikasi dua arah yang bercirikan penghargaan, perhatian, dan dukungan secara timbal balik dari pihak-pihak yang berkomunikasi. Walaupun pada kenyataannya, komunikasi yang beretika masih jauh dari harapan.

Sebagaimana yang sering dihadirkan dalam beberapa acara atau program televisi tentang pembahasan sebuah topik yang melibatkan pakar sebagai narasumber dalam penyampaian argumentasi maupun dalam memberikan sanggahan atau bantahan tidak mencerminkan perilaku komunikasi yang kurang santun, mendebat dengan saling menjatuhkan, menyerang dengan bahasa tidak mencerminkan kesopanan, menjadi bukti bahwa sampai pada hari ini etika komunikasi masih terpinggirkan bahkan bagi kalangan terdidik dan religius sekalipun. 
Oleh karena itu menarik kemudian untuk mengkaji lebih dalam etika komunikasi yang perlu dilakukan dalam berdiskusi sebagai sebuah konsep dasar yang dapat meminimalisir terjadinya konflik yang akan melahirkan perdebatan panjang dalam sebuah pertentangan.

\section{Metode Penelitian}

Penelitian ini merupakan penelitian kepustakaan yang mengkaji etika komunikasi dalam berdiskusi yang juga diintegrasikan dengan ilmu dakwah. Sumber primer diperoleh melalui literatur yang sesuai dengan dengan kajian yang dilakukan penulis. Ini menjadi pembeda antara penelitian yang dilakukan langsung di lapangan. Hanya saja, observasi tentunya dilakukan dengan mengamati proses diksusi dan juga sesuai dengan pengalaman dari penulis. Peneltiian ini bukan merupakan penemuan yang dilakukan dengan melakukan penyebaran kuisioner atau pun wawancara (Khatibah, 2011). Literatur yang sesuai dikumpulkan dengan teknik dokumentasi, yaitu membaca dan memperlajari serta mengkaji.

hal-hal yang sesuai dan berkaitan dengan kajian yang dilakukan. Penelitian ini merupakan penelitian kualitatif di mana peneliti sebagai instrumen kunci dan hasilnya lebih menekankan makna dari pada generalisasi (Sugiyono, 2014). Penulis menarik kesimpulan dari data yang telah dikaji sehingga menemukan pengembangan kajian baru.

\section{Hasil dan Pembahasan}

\section{Pengertian Etika Komunikasi}

Secara etimologi etika berasal dari bahasa Yunani, ethos=watak. Kata ethos ini mengandung mana bahwa semau batasan atau definisi etika membicarakan masalah baik buruk, bermoral atau tidak bermoral, susila dan tidak susila dari perbuatan atau tingkah laku manusia. Secara terminologi, Husaini mengemukakan bahwa etika adalah adab atau akhlak atau moral, yakni sebagai kumpulan aturan/ajaran tentang cara berperilau. Adab berasal dari kata addaba, yakni mendidik, melatih disiplin, memperbaiki, mengambil tindakan, sopan, berbudi baik (AlHusaini et al., 2015).

Menurut Magnis-Suseno dalam Kriyantono mendefinisikan etika sebagai filsafat moral atau ilmu tentang moralitas. Etika sebagai filasafat moral mengaji secara kritis dan mendasar tentang ajaran-ajaran/kumpulan moral tertentu dan hasil kajiannya dapat berupa ajaran-ajaran moral tertentu (Kriyantono, 2019).

Etika secara umum didefinisikan sebagai tata cara pergaulan, aturan perilau, adat kebiasaan manusia dalam bermasyarakat dan menentukan nilai baik dan nilai tidak baik. Sedangkan etika komunikasi adalah norma, nilai, atau ukuran tingkah laku baik dalam kegiatan komunikasi di suatu masyarakat (Mutiah et al., 2019).

Pearce menyebutnya dengan speech acts (tindak tutur). Keduanya mendeskripsikan tindak tutur sebagai tindakan-tindakan yang kita lakukan dengan berbicara, termasuk memuji, menghina, berjanji, mengancam, menyatakan, dan bertanya (West \& Turner, 2008). Tindak tutur menyampaikan niat pembicara dan mengindikasikan bagaimana komunikasi harus dijalankan. Tindak tutur bukanlah benda, tindak tutur adalah konfigurasi dari logika makna dan tindakan dari percakapan, dan konfigurasi ini dibangun bersama.

Sebagaimana praktiknya dalam kehidupan sehari-hari, dalam strategi komunikasi dikenal teori makrokognitif (karena melihat bagaimana kita menyusun pesan pada level tindakan yang sulit). Salah satunya adalah teori strategi kesopanan. Teori ini menyatakan bahwa dalam kehidupan sehari-hari kita merancang pesan yang dapat melindungi muka sekaligus mencapai tujuan lainnya. Brown dan Levinson percaya bahwa kesopanan sering kali merupakan tujuan 
karena kesopanan merupakan nilai universal secara kultural. Setiap kebudayaan memiliki derajat yang berbeda dalam hal kebutuhan terhadap kesopanan dan juga cara-cara yang berbeda untuk menjadi sopan, tetapi semua orang memiliki kebutuhan untuk dihargai dan dilindungi (Morissan, 2015).

Memilih perkataan yang baik sesungguhnya menjadi bagian dari upaya kita untuk menghargai orang lain dan diri kita sendiri. Artinya orang lain ketika berkomunikasi dengan kita juga akan mampu menghargai ketika kita juga menghargai mereka. Seringkali manusia tidak dihargai karena dirinya sendiri tidak mampu menghargai orang lain. Namun yang jelas, perintah berbuat baik tidak hanya terbatas pada ucapan, tetapi segala bentuk tindakan (tingkah laku) harus membuat nyaman sekitar.

Brown dan Levinson menyebutnya dengan face needs (kebutuhan wajah). Wajah positif adalah keinginan untuk dihargai dan diakui, untuk disukai dan dihormati, dan kesopanan positif dirancang untuk memenuhi keinginan ini. Menunjukkan perhatian, memberi pujian, dan menggunakan bentuk penyampaian yang terhormat adalah contohnya. Wajah negatif adalah keinginan untuk bebas dari gangguan atau kekacauan, dan kesopanann negatif dirancang untuk melindungi orang lain ketika kebutuhan wajah negatif terancam. Mengakui bahwa anda mengesankan ketika membuat sebuah permintaan merupakan sebuah contoh umum (Littlejohn \& Foss, 2010).

Stella Ting-Toomey dan Leeva Chung mengemukakan bahwa facework adalah mengenai strategi verbal dan nonverbal yang kita gunakan untuk memelihara, mempertahankan, atau meningkatkan citra diri sosial kita dan menyerang atau mempertahankan/menyelamatkan citra sosial orang lain. Dengan kata lain, facework berkaitan dengan bagaimana orang membuat apapun yang mereka lakukan konsisten dengan muka mereka. Ting-Toomey menyamakan facework dengan "tarian komunikasi yang berjinjit" (communication dance that tiptoes) antara rasa hormat bagi muka diri sendiri dan muka orang lain (West \& Turner, 2008).

\section{Percakapan sebagai Hakekat Diskusi}

Diskusi merupakan suatu proses komunikasi yang teratur dengan melibatkan sekolompok orang dalam interaksi tatap muka yang informal dengan berbagi pengalaman atau informasi, pengambilan kesimpulan, dan solusi atau pemecahan masalah (Darmadi, 2016). Oleh karena itu, diksusi dilakukan dengan berbagai oleh berbagai pihak dengan harapan dapat menghasilkan sebuah solusi atas pemecahan masalah yang memberikan dampak positif pada pengaplikasian diskusi yang dilakukan.

Paul Grive (dalam Morissan) mengemukakan seperangkat asumsi umum yang harus dimiliki setiap percakapan untuk dapat menghasilkan percakapan yang koheren yaitu percakapan yang logis dan mudah dimengerti. Pertama adalah prinsip kerja sama (cooperative principle) yang menuntut peserta percakapan memberikan kontribusinya kepada percakapan secara patut. Kerja sama tidak berarti harus ada ungkapan persetujuan, tetapi kerja sama berarti adanya keinginan peserta untuk memberikan kontribusi yang sesuai dengan tujuan percakapan (Morissan, 2015).

Misalnya, jika seseorang mengajukan pertanyaan kepada Anda maka Anda harus menjawab atau menaggapinya dengan cara sekurang-kurangnya Anda mengakui adanya pertanyaan. Jika tida maka Anda akan dinilai tidak sopan. Kita merasa terganggu ketika orang yang kita tanya gagal menyelesaikan ucapannya dengan patutu karena dapat menimbulkan kebingungan sehingga percakapan menjadi tidak koheren. 
Inilah yang disebut sebagai teori aturan percakapan. Menurut Grice, kerja sama dalam percakapan dapat dicapai melalui empat aturan yaitu: perkataan berkuantitas (quantity maxim); perkataan berkualitas (quality maxim); perkataan relevan (relevancy maxim); dan perkataan berperilaku (manner maxim).

Kontribusi peserta kepada suatu percakapan harus memberikan informasi yang cukup dan tidak berlebihan. Dalam hal ini, melanggar quantity maxim ketika perkataan Anda tida memberikan cukup informasi atau terlalu banyak informasi. Perkataan yang Anda ucapkan haruslah benar, dan Anda melanggar quality maxim ketika Anda secara sengaja berbohong atau berkomunikasi dengan cara-cara yang tida menunjukkan suatu maksud yang jujur.

Percakapan harus relevan, dan Anda melanggar relevancy maxim ketika Anda mengatakan sesuatu yang tida berhubungan. Anda melanggar manner maxim ketika Anda berbicara tidak jelas, mendua (ambigu) dan tidak teratur.

Prinsip kerja sama dan keempat aturan tersebut sering kali dilanggar, dan terkadang disengaja termasuk di dalam sebuah diskusi formal. Tetapi apa yang membuat prinsip kerja sama dan aturan tersebut menjadi penting adalah bahwa pembicara tidak pernah melanggar aturan tanpa menghentikan aliran percakapan atau memengaruhi persepsi pererta. Dengan kata lain, pelanggaran merupakan masalah yang harus ditangani bersama-sama di antara peserta.

Percakapan dalam diskusi merupakan serangkaian tindakan bicara yang dikontrol oleh sejumlah aturan. Menurut Rogers dan Millar (dalam Morissan), ketika seseorang (pihak pertama) membuat suatu pernyataan, maka orang lain (pihak kedua) dapat memberikan tanggapan dengan menggunakan salah satu cara dari tiga cara yang tersedia. Pihak kedua dapat menerima pernyataan itu, cara ini disebut dengan istilah one-down (menerima). Dia dapat membuat pernyataan tandingan, yang berarti menolak, cara ini disebut dengan one-up (tandingan). Cara ketiga disebut one-across yaitu tidak menerima tetapi tidak juga menolak (netral). Piha kedua memberikan tanggapan dengan cara yang tidak terlalu menerima upaya piha pertama untuk melakukan kontrol. Misalnya dengan cara mengajukan pertanyaan, mengubah topik pembicaraan, atau menunda pembicaraan (Morissan, 2015)

Dengan demikian terdapat tiga cara memberikan tanggapan yaitu: menerima, tandingan, dan netral. Seseorang yang lebih banyak menyampaikan pesan tandingan dalam periode waktu tertentu dikatakan sebagai dominan, dengan catatan selama pihak lain menerima kondisi tersebut

Dalam komunikasi dikenal dengan istilah gaya komunikasi. Myers-Briggs dalam (Liliweri, 2010) menyebutkan bahwa dalam praktiknya dikenal tiga gaya utama komunikasi yaitu: Pertama. Gaya agresif dengan kategori indikator yaitu tertutup, sedikit mendengarkan, sukar mendengar pandangan orang lain, interupsi, dan menopoli pembicaraan; Kedua. Gaya pasif dengan kategori indikator yaitu tidak langsung, selalu sepakat, tidak pernah bicara lebih dahulu dan ragu-ragu; Ketiga. Gaya asertif dengan kategori indikator yaitu efektif dan aktif mendengarkan, sedikit pernyataan dan selalu ada pengharapan, menyatakan pengamatan dan tidak pernah beri label atau penilaian, ekspresi diri secara langsung dan segera menyatakan perasaan atau keinginan, serta cek perasaan orang lain.

Dari ketiga gaya komunikasi tersebut diikuti dengan tanda-tanda nonverbal yaitu: Pertama. Gaya agresif ditandai dengan suka menunjuk pakai telunjuk, dahi berkerut, menatap dengan tajam dan kritis, tatapan mata, tampil dingin, suara nyaring dan ceplas-ceplos; Kedua. Gaya pasif ditandai dengan selalu gelisah, selalu angguk kepala kalau berkomunikasi, jarang 
ekspresikan wajah, senyum dan angguk tanda setuju, mata selalu sayu dan sedih, tampilan tubuh melorot, volume suara rendah, waktu bicara nada suara meningkat dan ragu-ragu ketika ada kecemasan; Ketiga. Gaya asertif ditandai dengan gestur alamiah dan terbuka, sangat atensi dan ekspresi wajah menarik, tampilan tubuh percaya diri dan santai, volume suara tepat dan ekspresif, dan bicara dengan nada yang bervariasi.

\section{Etika Komunikasi dalam Berdiskusi yang Sejalan dengan Dakwah}

Sudah menjadi hal yang sangat penting bagi manusia menjalankan etika dalam kehidupan sehari-hari sebagai sebuah nilai yang dianut dalam kehidupan. Tidak terkecuali

etika komunikasi yang diharapkan dalam membetuk masyarakat yang harmonis dan jauh dari konflik dan perdebatan. Dalam diskusi misalnya, yang menjadi inti dari hal tersebut bukanlah sebuah kemenangan ide atau gagasan salah satu pihak, tetapi bagaimana menemukan sebuah solusi atau kebenaran dengan bertukar pikiran.

Berdiskusi memang berisiko memunculkan kesalahpahaman dan ketidaksepakatan di antara pihak yang ada dalam forum diskusi. Oleh karena itu dibutuhkan diskusi dengan cara terbaik, yaitu mendengarkan dan menghargai pendapat orang lain. Hal tersebut sejalan dengan QS. al-Nahl: 125 sebagai berikut:

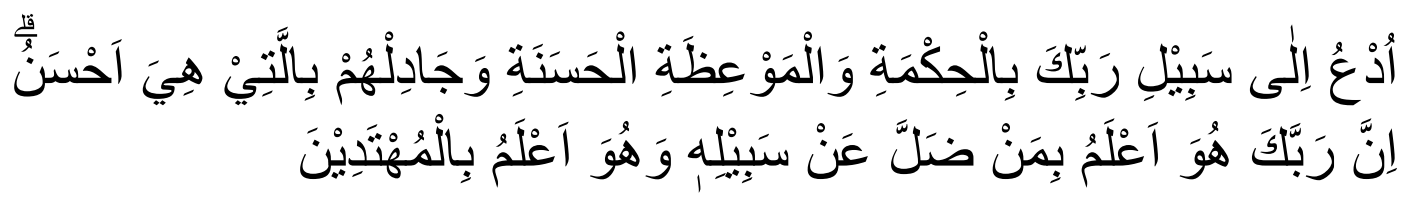

Serulah (manusia) kepada jalan Tuhanmu dengan hikmah dan pengajaran yang baik, dan berdebatlah dengan mereka dengan cara yang baik. Sesungguhnya Tuhanmu, Dialah yang lebih mengetahui siapa yang sesat dari jalan-Nya dan Dialah yang lebih mengetahui siapa yang mendapat petunjuk" (Kementerian Agama RI, 2017).

Kata (حكمة) hikmah antara lain berarti yang paling utama dari segala sesuatu, baik pengetahuan maupun perbuatan. Ia adalah pengetahuan atau tindakan yang bebas dari kesalahan atau kekeliruan. Hikmah juga diartikan sebagai sesuatu yang bila digunakan/diperhatikan akan mendatangkan kemaslahatan dan kemudahan yang besar atau lebih besar serta menghalangi terjadinya mudharat atau kesulitan yang besar atau lebih besar. Makna ini ditarik dari kata hakamah, yang berarti kendali, karena kendali menghalangi hewan/kendaraan mengarah ke arah yang tidak di inginkan atau menjadi liar. Memilih perbuatan yang terbaik dan sesuai adalah perwujudan dari hikmah. Memilih yang terbaik dan sesuai dari dua hal yang buruk pun dinamai hikmah, dan pelakunya dinamai hakim (bijaksana). Siapa yang tepat dalam penilaiannya dan dalam pengaturannya, dialah yang wajar menyandang sifat ini atau dengan kata lain dia yang hakim. Thahir Ibn „Asyur menggaris bawahi bahwa hikmah adalah nama himpunan segala ucapan atau pengetahuan yang mengarah kepada perbaikan keadaan dan kepercayaan manusia secara bersinambung. Thabathaba"i mengutip ar-Raghib alAshfihani yang menyatakan secara singkat bahwa hikmahadalah sesuatu yang mengena kebenaran berdasar ilmu dan akal. Dengan demikian, menurut Thabathaba ${ }^{\mathrm{ec}} \mathrm{i}$, hikmah adalah argumen yang menghasilkan kebenaran yang tidak diragukan, tidak mengandung kelemahan tidak juga kekaburan (Shihab, 2011).

Dalam implementasinya, Islam mengajarkan untuk berdiskusi dengan memberi manfaat, menggunakan kalimat yang baik dan sopan, bersikap lemah lembut, dengan melalui diskusi 
dengan penuh hati-hati dan tenang serta mengutamakan untuk menahan amarah dan berlapang dada menerima pendapat orang lain. Dalam proses diskusi sebaiknya dimuat dalam forum yang harmoni, berusaha memberikan argumentasi yang berorientasi pada kebenaran dan menciptakan suasana yang santai dan nyaman. Hal terpenting adalah bagaimana forum

diskusi tersebut berjalan dengan penuh sikap saling menghargai tanpa memperlihatkan keegoisan pribadi.

Melalui cara tersebut, diksusi akan melahirkan kesepakatan yang dapat diterima dengan baik oleh semua pihak. Tidak meninggalkan jejak kebencian dan melahirkan sebuah kebenaran untuk kemaslahatan bersama, bukan kemenangan sepihak belaka. Diskusi tentu harus berjalan dengan menggunakan akals sehat, tidak mencampurkan antara masalah pribadi dan masalah dalam forum tersebut. Memang dibutuhkan sebuah profesionalisme untuk terlibat dalam sebuah forum diskusi agar dapat menempat diri sesuai dengan porsinya (Anwar, 2018).

Dalam etika komunikasi, yang harus dilakukan berbagai pihak yang ada dalam forum diskusi tersebut adalah sebagai berikut:

1. Fokus pada pembahasan

Dalam mengikuti sebuah diskusi, memperhatikan pesan-pesan komunikasi dalam diskusi tersebut harus dilakukan agar tidak salah dalam menginterpretasikan isi pesan yang diterima.

2. Jangan menimpali pembicaraan

Komunikan harus mendahulukan komunikator menyampaikan pesan-pesan komunikasi hingga selesai. Komunikan tidak semestinya memotong pembicaraan komunikator karena komunikan yang baik adalah komunikan yang menghargai segala bentuk pendapat yang didengarnya. Jika menganggap tidak sesuai dengan gagasannya, barulah berbicara ketika lawan bicara telah selesai mengutarakan gagasannya terlebih dahulu.

3. Menggunakan bahasa lemah lembut

Bahasa menjadi salah satu hal terpenting dalam proses komunikasi yang dilakukan manusia. baik itu baha tubuh, maupun bahasa lisan. Bahasa perlu disampaikan dengan lemah lembut agar komunikan dapat menerima pesan yang disampaikan. Maka dari itu, dalam komunikasi ditekankan untuk menyampaikan argumentasi dengan baahsa yang lembut sehingga dapat diterima oleh semua pihak yang ada dalam forum. Tidak berteriak-teriak, memukul meja dan sebagainya.

4. Memberikan orang lain kesempatan

Proses tukar pendapat dalam diskusi tidak akan pernah terlepas dari sebiah perbedaan argumentasi. Hal tersebut wajar dan biasa terjadi. Namun, yang perlu diperhatikan adalah setiap pihak harus memberikan kesempatan bagi pihak lain untuk memberikan pendapatnya dengan tidak menimpali agar pesannya tersampaikan. Selain itu, ini jadi bentuk etika menghargai pendapat orang lain sehingga tidak tersinggung.

5. Hadirkan humor

Untuk menghindari diskusi yang alot, diperlukan sikap humoris yang cukup untuk membuat suasanan lebih santai. Humor sebagai kode budaya dan kode bahasa merupakan hasil budaya masyarakat pendukungnya sehingga identitasnya sebagai humor hanya dapat diberi makna sepenuhnya oleh masyarakat itu sendiri. Adanya bahasa dapat memperlancar dan mempermudah proses komunikasi dalam masyarakat (Wijana, 2013). Dengan 
dihadirkannya humor dalam sebuah diskusi, akan memberikan kelancaran dalam penyampaian pendapat tanpa saling berkutat dengan emosi yang berkepanjangan.

Uraian di atas sejalan juga al-Qurean yang dapat diterapkan dalam berdiskusi, di antaranya dimulai dengan niat yang tulus, fokus mendengarkan dan memperhatikan, memberikan argumentasi yang akurat dan benar, lugas dalam beretorika, objektif dan adil, kooperatif, bersedia mengalah dan tidak egois. Dengan begitu, penerapan etika tersebut dapat menghindarkan semua pihak dari berbagai konflik dalam berdiskusi sehingga mencapai tujuan bersama (Zulfikar, 2019). Hal tersebut juga sebaiknya didukung sifat amanah yang artinya terpercaya, dapat dipercaya. Dalam diskusi, setiap pihak sebaiknya menyampaikan kebenaran sesungguhnya dan tidak menyembunyikannya. Hanya saja yang perlu diperhatikan adalah penyampaiannya harus dilakukan dengan tidak menyudutkan pihak tertentu secara sengaja. Selain itu, Fathanah juga sebaiknya diaplikasikam untuk dapat mengerti situasi dan kondisi di sekitarnya. Sehingga dengan begitu, ia mampu menganalisis dan mendalami situasi yang sedang dihadapinya. Terutama harus dapat memahami apa yang seharusnya dilakukan dan sebaiknya tidak dilakukan dalam situasi berdiskusi (Qudratullah, 2019).

\section{Kesimpulan}

Dalam berdiskusi, memilih perkataan yang baik sesungguhnya menjadi bagian dari upaya kita untuk menghargai orang lain dan diri kita sendiri. Artinya orang lain ketika berkomunikasi dengan kita juga akan mampu menghargai ketika kita juga menghargai mereka. Seringkali manusia tidak dihargai karena dirinya sendiri tidak mampu menghargai orang lain. Namun yang jelas, perintah berbuat baik tidak hanya terbatas pada ucapan, tetapi segala bentuk tindakan (tingkah laku) harus membuat nyaman sekitar. Islam mengajarkan untuk berdiskusi dengan memberi manfaat, menggunakan kalimat yang baik dan sopan, bersikap lemah lembut, dengan melalui diskusi dengan penuh hati-hati dan tenang serta mengutamakan untuk menahan amarah dan berlapang dada menerima pendapat orang lain. Dalam proses diskusi sebaiknya dimuat dalam forum yang harmoni, berusaha memberikan argumentasi yang berorientasi pada kebenaran dan menciptakan suasana yang santai dan nyaman. Hal terpenting adalah bagaimana forum diskusi tersebut berjalan dengan penuh sikap saling menghargai tanpa memperlihatkan keegoisan pribadi. 


\section{Bibliografi}

Al-Husaini, M., Bishop, J. M., Al-Foudari, H. M., \& Al-Baz, A. F. (2015). A review of the status and development of Kuwait"s fisheries. Marine Pollution Bulletin, 100(2), 597- 606.

Anwar, M. (2018). Menjadi guru profesional. Prenada Media.

Darmadi, H. (2016). Tugas, peran, kompetensi, dan tanggung jawab menjadi guru profesional. Edukasi: Jurnal Pendidikan, 13(2), 161-174.

Kementerian Agama RI. (2017). Kementerian Agama RI, 2017.

Khatibah, K. (2011). Penelitian kepustakaan. Iqra': Jurnal Perpustakaan Dan Informasi, 5(01), 36-39.

Kriyantono, R. (2019). Pengantar Lengkap Ilmu Komunikasi Filsafat dan Etika Ilmunya Serta Perspekfif Islam. Prenada Media.

Liliweri, A. (2010). Komunikasi serba ada serba makna. Kencana.

Littlejohn, S. W., \& Foss, K. A. (2010). Theories of human communication. Waveland

press.Morissan, M. (2015). Teori Komunikasi Individu Hingga Masa. Prenada Media.

Mutiah, T., Albar, I., Fitriyanto, A. R., \& Rafiq, A. (2019). Etika Komunikasi dalam menggunakan Media Sosial.

Pujiati, T., \& Triadi, R. B. (2016). Pengaruh Konsep Diri Dan Budaya Dalam Komunikasi Interpersonal. Proceedings, 1(1).

Qudratullah, Q. (2019). Konsep Jurnalisme Dakwah Dalam Mencegah Tindak Korupsi. NUANSA: Jurnal Penelitian IImu Sosial Dan Keagamaan Islam, 16(2), 294. https://doi.org/10.19105/nuansa.v16i2.2642

Shihab, M. Q. (2011). Tafsïr Al-Mishbah (Pesan, Kesan dan Keserasian al-Qur'ān). Lentera Hati.

Sugiyono. (2014). Metode Penelitian Kuantitatif, Kualitatif dan Kombinasi (Mixed Methods).

Alfabeta.

West, R., \& Turner, L. H. (2008). Pengantar teori komunikasi: analisis dan aplikasi. Jakarta: Salemba Humanika.

Wijana, I. D. P. (2013). Pemakaian Bahasa Dalam Karya Ilmiah Populer. Jurnal Arbitrer, 1(1), 19-36. 
Qudratullah, Rosniar 